\title{
Comparative Jejunal Expression of TFRC gene in Pigs Differentially Adhesive to Diarrhoeagenic $E$. coli
}

\author{
Chandrakanta Rawat $^{1 *}$, Nihar Ranjan Sahoo ${ }^{2}$, Shivaji S. Wagh ${ }^{1}$, \\ D. Verma Ankita ${ }^{3}$ and Kanti Raje ${ }^{4}$ \\ ${ }^{1}$ Division of Animal Genetics, ICAR-Indian Veterinary Research Institute, Izatnagar, \\ Bareilly, U.P-243122 India \\ ${ }^{2}$ Livestock Production \& Management Section, ICAR-Indian Veterinary Research Institute, \\ Izatnagar, Bareilly U.P-243122, India \\ ${ }^{3}$ Department of Animal Genetics \& Breeding, Col. of Vet. Sci. \& A.H. \\ Junagarh, Gujrat, India \\ ${ }^{4}$ Division of Animal Nutrition, ICAR-Indian Veterinary Research Institute, Izatnagar, \\ Bareilly, U.P-243122, India
}

*Corresponding author

\begin{tabular}{|c|c|}
\hline & A B S T R A C T \\
\hline $\begin{array}{l}\text { Ke y w o r d s } \\
\text { Adhesion pattern, } \\
\text { E. coli, Desi pig, } \\
\text { TFRC, Jejunal } \\
\text { expression profiling }\end{array}$ & \multirow{3}{*}{$\begin{array}{l}\text { Diarrhoea in piglets due to Escherichia coli is an important problem in the pig farming } \\
\text { industry. Adhesion of these bacteria to the epithelial cells of small intestine is an essential } \\
\text { prerequisite for the incidence of diarrhoea. Among the putative candidate genes associated } \\
\text { with adhesion pattern, TFRC (transferrin receptor) gene was localized on targeted region } \\
\text { of SSC13 and considered as a positional candidate gene. The present investigation was } \\
\text { conducted to evaluate the Indian desi pigs in terms of } E \text {. coli adhesion pattern (with Indian } \\
\text { isolate) and study TFRC expression profile in different adhesion phenotypes. A total of } 4 \\
\text { types of adhesion pattern were observed with different frequencies. RT-PCR analysis } \\
\text { revealed that TFRC mRNA expression level was different across the differentially } \\
\text { adhesive phenotypes. The increased level of TFRC expression indicates its role in } \\
\text { immunity against } E \text {. coli mediated diarrhoea. }\end{array}$} \\
\hline Article Info & \\
\hline $\begin{array}{l}\text { Accepted: } \\
\text { 10 June } 2018 \\
\text { Available Online: } \\
10 \text { July } 2018\end{array}$ & \\
\hline
\end{tabular}

\section{Introduction}

Pig Rearing is one of the important conventional activities carried out by rural India. It has got tremendous potential to contribute higher economic gain to the rural poor especially the tribal population. According to $19^{\text {th }}$ livestock census (2012) India posses 10.29 million pigs with which it contribute about $1 \%$ of world pig population. Pig population was gradually declining after 2003 in our country which is because of diseases, social taboos on pig rearing and lack of breeder farmers. As pig is very much prone to diseases, which is one of the most important is piglet diarrhoea. Escherichia coli are the major pathogenic bacteria causing diarrhoea in swine, which accounts for $56.2 \%$ of the 
incidence of piglet diarrhoea and $24.7 \%$ of the mortality from diarrhoea (Shi, 2003). This organism can adhere and colonize at the brush border membrane of the epithelial cells of a piglet's small intestine through its fimbriae and secrete enterotoxins (Sellwood et al., 1975). An enterotoxin stimulates the small intestine for secreting massive fluid and electrolyte into the gut lumen resulting diarrhoea. Therefore, adhesion to the epithelial cells of the small intestine is an essential prerequisite for the bacteria to cause diarrhoea among piglets. However, not all piglets are equally susceptible to E. coli. Certain piglets are innately resistant, as they can prevent the adhesion of $E$. coli to the epithelial cells of small intestine. The adhesion difference happens because of the presence or absence of specific bacterial adhesin receptors in the small intestine epithelial cells of the host. These receptors are not present in each and every pig and their absence can cause resistance to $E$. coli induced diarrhoea (Sellwood et al., 1975). The adhesion was found to be genetically controlled and inherited in a dominant fashion (Bijlsma et al., 1982). However, the exact/specific genes that encode for the receptor/susceptibility are not yet known. The genetically determined differential adhesion pattern or resistance can help in identifying the genetic cause for susceptibility which can potentially be explored for an effective selection program. The locus encoding the intestinal receptor responsible for adhesion was mapped to the q41 region on pig chromosome 13 (SSC13) by different linkage analyses. TFRC is one among the putative positional candidate genes found in this region.

In India, there are several reports of incidences of piglet diarrhoea in various organized farms of different parts of India (Anonymous, 2014). Yet there is scarcity of literature on the existence as well as inheritance of the receptors controlling the adhesion pattern in
Indian pig population which if explored could be utilized to enhance genetic resistance against piglet diarrhoea. Hence, the study was designed with the objectives to evaluate the Indian desi pigs in terms of $E$. coli adhesion pattern (using Indian isolate of diarrhoeagenic E. coli) and to study the jejunal expression profile of TFRC in different adhesive phenotypes.

\section{Materials and Methods}

\section{Experimental animals and tissue collection}

A total of 150 desi pigs slaughtered in different places of Bareilly, U.P. were screened for E. coli adhesion pattern. Jejunum tissue samples were collected within $30 \mathrm{~min}$ of slaughter and brought to laboratory in ice maintaining sterile condition. After cleaning it properly with cold PBS, a small part $(250 \mathrm{mg}$ ) of the sample was stored in $1 \mathrm{ml}$ RNA later solution at $-20^{\circ} \mathrm{C}$ for RNA isolation. The rest part of jejunum (approximately $2 \mathrm{~cm}$ ) was kept at $4^{\circ} \mathrm{C}$ for the Microscopic Adhesion Test (MAT) on the same day. Samples were screened for adhesion pattern of the porcine brush border epithelial cells with Indian isolate of diarrhoeagenic E. coli through MAT as described by Li et al., (2007).

\section{Bacterial strain and preparation of suspension}

The E. coli strains were isolated from diarrhoeic piglets of All India Co-ordinated Research Project (AICRP) on Pig, Indian Veterinary Research Institute (IVRI) unit, Bareilly, U.P., India and characterized biochemically and sequencing of partial $16 \mathrm{~S}$ ribosomal RNA gene (KJ810542). The isolate was cultured in BHI agar plate for overnight at $37^{\circ} \mathrm{C}$ and a single colony was picked up from BHI agar plate for inoculation in LB broth medium (Trypton, Yeast extraction, $\mathrm{NaCl}, \mathrm{pH}$ $7.0-7.2)$ at $37^{\circ} \mathrm{C}$ for $16-18$ hours at $1800 \mathrm{rpm}$. 
The optical density was checked for 1.0 at 520 $\mathrm{nm}$. The culture was preserved at $4^{0} \mathrm{C}$ for use at the same day.

\section{Preparation of brush border epithelial cells}

The small intestine was separated from the mesentery, and for isolation of intestinal brush borders, a piece of mid jejunum (approx. 2 $\mathrm{cm}$ ) about $1 \mathrm{~m}$ proximal to the ileocaecal valve was excised from the small intestine within 30 min of slaughter. It was cut opened along the longitudinal axis and washed with cold PBS ( $\mathrm{pH}$ 7.4) containing 0.1 M EDTA to make free of contents and placed on ice until processing. Subsequently, the sample was immersed in a cold hypotonic EDTA solution (5 mM EDTA, adjusted to $\mathrm{pH} 7.4$ with $\mathrm{Na}_{2} \mathrm{CO}_{3}$ ) for $20 \mathrm{~min}$ and rinsed gently to eliminate debris. Epithelial cells were removed by scraping the mucosal surface of the jejunum with the edge of a glass microscopic slide and immersed in the cold hypotonic EDTA solution for $30 \mathrm{~min}$. Then the enterocytes were homogenized with tissue homogenizer (Star Micronic Devices) till even suspension of tissue made and filtered through clean muslin cloth. The filtrate was centrifuged at $3500 \mathrm{rpm}$ for $10 \mathrm{~min}$ to pellet and cells were re-suspended in 5-6 ml cold PBS. The process of re-suspension and centrifugation was repeated twice. Brush border suspension was added with $100 \mu 1$ gentamicin sulfate $(1 \mathrm{mg}$ per $\mathrm{ml})$ and sodium azide $(3 \mathrm{mM})$ to make a final concentration of $1 \times 10^{6}$ cells per $\mathrm{ml}$ and stored at $4^{0} \mathrm{C}$ for use at the same day.

\section{Adhesion test}

Equal volume of brush border cell suspension and fresh bacterial suspension (100 $\mu$ l each) was mixed in $6 \mathrm{ml}$ tissue culture plate and incubated for $30 \mathrm{~min}$ at $37^{\circ} \mathrm{C}$ at $200 \mathrm{rpm}$. A drop of the mixed suspension was examined for the adhesion pattern using a light microscope under $40 \mathrm{X}$ objectives. A single epithelial cell was considered adhesive when more than five bacteria adhering to the brush border membrane. Animals were classified as strongly adhesive, adhesive, weakly adhesive and non-adhesive as per Li et al., (2007). Twenty well separated and intact enterocytes were checked from the epithelial cell specimen of each animal.

\section{Isolation of total RNA and first strand cDNA synthesis}

The animals with different adhesion patterns (6 samples each) were subjected to jejunal expression profiling of TFRC gene. Total RNA was isolated from jejunum tissue using Trizol reagent (Thermo Scientific, USA) and chloroform (Sambrook and Russell, 2001) according to manufacturer's protocol and was precipitated using isopropanol, washed twice with $70 \%$ ethanol and stored at $-80^{\circ} \mathrm{C}$. The quality and quantity was checked by nanodrop spectrophotometer against nuclease free water as blank and RNA samples showing the $\mathrm{OD}_{260}$ : $\mathrm{OD}_{280}$ values more than 1.8 were used. The quality and integrity was also checked using denaturing agarose gel electrophoresis to reveal two intact bands of $28 \mathrm{~S}$, and $18 \mathrm{~S}$ with smearing in between. For synthesis of first strand cDNA, reverse transcription was carried out in $20 \mu \mathrm{l}$ reaction mixtures using Revert Aid H Minus First Strand cDNA Synthesis Kit (Thermo Scientific, USA) as per manufacturer's instruction. Total RNA of $1 \mu \mathrm{g}$ for each reaction was dissolved in nuclease free water and oligo $(\mathrm{dT})_{18}$ primer was added to make the final volume of $12 \mu \mathrm{l}$. The components $(5 \mathrm{x}$ reaction buffer; RiboLock RNase Inhibitor; $10 \mathrm{mM}$ dNTP Mix and RevertAid H Minus M-MuLV Reverse Transcriptase) were added to the tube for reverse transcription. Reaction mixture was incubated at $42^{\circ} \mathrm{C}$ and $70^{\circ} \mathrm{C}$, for $60 \mathrm{~min}$ and 5 min, respectively and finally at $4^{\circ} \mathrm{C}$ forever. The integrity of the cDNA was checked by PCR with porcine GAPDH primers (Nygard $e t$ al., 2007) to yield $90 \mathrm{bp}$ amplicon. 


\section{Real time PCR}

The resulting cDNAs were used for quantitative RT-PCR reactions with two sets of primers (Table 1) one from TFRC gene and other from GAPDH (as housekeeping gene). Quantitative Real-time PCR was performed with SSO Fast Eva Green ${ }^{\circledR}$ qPCR kit (Biorad) using Agilent Mx3005P QPCR System (USA) operated by MxPro QPCR software. The primer efficiencies were determined by running a standard curve for each assay prior to processing experimental samples. A standard curve was obtained by levels of 6 serial dilutions of cDNA as template and a regression equation in relation to the threshold values $(\mathrm{Ct})$ was formulated. The primer efficiency within range of $90-115 \%$ was considered to be good. A no template control (Master Mix and primers) was put for gene quantification for checking contamination in the reaction components. The Master Mix was prepared using $8.0 \mu \mathrm{l}$ of nuclease free water, $10 \mu \mathrm{M}$ of forward and reverse primers each and $10 \mu \mathrm{l}$ of Eva green mix (BioRad) and $1 \mu \mathrm{l}$ of cDNA was added. A qPCR amplification programme was used (One cycle of Hot start $\mathrm{PCR}$ at $95^{\circ} \mathrm{C}$ for $20 \mathrm{sec}$ followed by 40 cycles of denaturation at $95^{\circ} \mathrm{C}$ for $3 \mathrm{sec}$ and annealing/ extension at $58^{\circ} \mathrm{C}-60^{\circ} \mathrm{C}$ for 30 $\mathrm{sec})$. The amplification and denaturation data was acquired and cycle threshold $(\mathrm{Ct})$ values as well as amplification plot for all determined factors were estimated.

\section{Quantification of candidate gene expression}

Once the $\mathrm{C}_{\mathrm{T}}$ value is collected for each reaction, it can be used to generate a relative expression level. In our experiment, there were four conditions (Non-adhesive, Weakadhesive, Adhesive and Strong adhesive), where we measured the levels of TFRC gene compared to an endogenous control gene (GAPDH) using the method described by Livak and Schmittgen (2001). Between the three selected groups, non-adhesive samples were taken as control. The statistical significance of differences $(\mathrm{P}<0.05)$ in mRNA expressions of the examined factors was assessed by using one way ANOVA with Tukey's Multiple Comparison Test as post hoc was performed to determine the significant differences between dCTs of the analyzed groups.

\section{Results and Discussion}

The results of the qPCR allowed us to compare gene expression differences between non adhesive group with adhesive groups (which includes weak adhesive, adhesive and strong adhesive). RT-PCR analysis revealed that porcine TFRC mRNA expression was different across adhesive phenotypes (Figure 1) with the highest level in the strongly adhesive followed by adhesive; moderate levels in the weakly adhesive and low levels in the non-adhesive type. The mRNA expression of TFRC gene was found to be 2.47, 3.17 and $4.11 \log _{2}$ fold difference of in weak adhesive, adhesive and strong adhesive groups respectively, as compared to non adhesive group which was found to be statistically significant $(\mathrm{P}<0.05)$. Jacobsen et al., (2011) also examined by qRT-PCR the TFRC expression in F4ab,acR+ and F4ab,acRYorkshire piglets and found no significant expression differences.

Schroyen et al., (2013) reported an upregulation of TFRC in the F4ab, acR+ nondiarrhoeal group in comparison to the two other groups (F4R+ with diarrohea and F4Rwithout diarrohea). This suggests that TFRC is not a receptor for the fimbriae but its observed upregulation can be a consequence of the F4ab,acR+ piglet's ability to raise an effective immune response. It is seen that an activation of immune cells can increase TFRC expression in the inflamed gut mucosa (Harel et al., 2011). 
Table.1 Primer sequences used for relative quantification of TFRC gene using real time qPCR

\begin{tabular}{|l|l|l|l|}
\hline Target gene & Primer name & Sequence of nucleotide (5'-3') & Frag. size (bp) \\
\hline TFRC & $\begin{array}{l}\text { RT_TFRC_F } \\
\text { RT_TFRC_R }\end{array}$ & $\begin{array}{l}\text { F:GGCTTTGAAGAACCAGATCG } \\
\text { R:TGGGCAAGGTTCAATAGGAG }\end{array}$ & 110 \\
\hline GAPDH & $\begin{array}{l}\text { GAPDH_F } \\
\text { GAPDH_R }\end{array}$ & $\begin{array}{l}\text { F:ACACTCACTCTTCTACCTTTG } \\
\text { R:CAAATTCATTGTCGTACCAG }\end{array}$ & 90 \\
\hline
\end{tabular}

Figure.1 Jejunal expression of TFRC mRNA using quantitative RTPCR

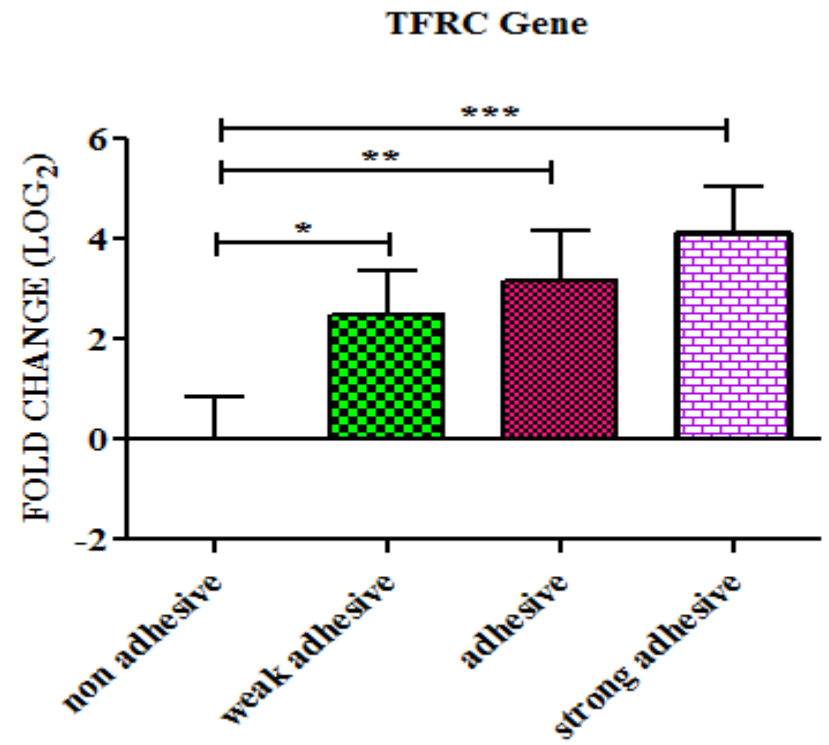

TFRC expression was specific for the midjejunum. TFRC expression was also measured in liver tissue. It was seen that the upregulation in the non-diarrhoeal $\mathrm{F} 4 \mathrm{ab} / \mathrm{ac} \mathrm{R}+$ group did not appear in the liver, suggesting that the up-regulation of TFRC was local and physiologically triggered by the state of the small intestine. Thus, TFRC was not just a functional, but a positional functional candidate gene (Schroyen et al., 2013). In conclusion, the increased level of TFRC expression along with degree of adhesion indicates its role in immunity against $E$. coli mediated diarrhoea.

\section{Acknowledgements}

The authors are thankful to the Director, Indian Veterinary Research Institute, Izatnagar, India for providing necessary funds and facilities to carry out this work. We are also thankful to owners of various slaughter houses of Bareilly for facilitating collection of biological samples. 
References

Anonymous, 2014. Annual Report 2014-15. All India Co-ordinated Research Project on Pig. National Research Centre on Pig, Rani, Guwahati, India pp: $1-42$.

Bijlsma, I.G., de Nijs, A., van der Meer, C. and Frik, J.F. 1982. Different pig phenotypes affect adherence of Escherichia coli to jejunal brush borders by K88ab, K88ac, or K88ad antigen. Infect Immun. 37: 891-894.

Harel, E., Rubinstein, A., Nissan, A., Khazanov, E., Milbauer, M. N., Barenholz, Y. and Tirosh, B. 2011. Enhanced transferrin receptor expression by proinflammatory cytokines in enterocytes as a means for local delivery of drugs to inflamed gut mucosa. PLoS One 6: e24202.

Jacobsen, M., Cirera, S., Joller, D., Esteso, G., Kracht, S. S., Edfors, I., Bendixen, C., Archibald, A. L., Vogeli, P., Neuenschwander, S., Bertschinger, $\mathrm{H}$. U., Rampoldi, A., Andersson, L., Fredholm, M. and Jorgensen, C. B. 2011. Characterisation of five candidate genes within the ETEC F4ab/ac candidate region in pigs. BMC Res Notes. 4: 225.

Li, Y., Qiu, X., Li, H. and Zhang, Q. 2007. Adhesive Patterns of Escherichia coli F4 in Piglets of Three Breeds. Journal of Genetics and Genomics. 34: 591-
599.

Livak, K. J. and Schmittgen, T. D. 2001. Analysis of relative gene expression data using real-time quantitative PCR and the $2-\triangle \Delta \mathrm{CT}$ method. Methods. 25(4): 402-408.

Nygard, A.B., Jorgenson, C.B., Cierra, S. and Fredholm, M. 2007. Selection of reference genes for gene expression studies in pig tissues using SYBR green qPCR. BMC Molecular Biology. 8: 67.

Sambrook, J. and Russell, D.W. 2001. Molecular Cloning: A Laboratory Manual. Third ed. Cold Spring Harbor Laboratory Press, NY, USA, pp. 527535.

Schroyen, M., Stinckens, A., Verhelst, R., Janssens. S., Cox, E., Goddeeris, B. M., Georges, M., Niewold, T. and Buys, N. 2013. The effect of enterotoxigenic Escherichia coli F4ab/ac on early-weaned piglets: a gene expression study. Vet Immunol Immunopathol. 15: 152(1-2).

Sellwood, R., Gibbons, R.A., Jones, G.W. and Rutter, J.M. 1975. Adhesion of enteropathogenic Escherichia coli to pig intestinal brush borders: the existence of two pig phenotypes. J Med Microbiol. 8: 405-411.

Shi, Q.S., 2003. The review of the receptors of ETEC F4. Pigs and Poultry. 23: $33-35$.

\section{How to cite this article:}

Chandrakanta Rawat, Nihar Ranjan Sahoo, Shivaji S. Wagh, D. Verma Ankita and Kanti Raje. 2018. Comparative Jejunal Expression of TFRC gene in Pigs Differentially Adhesive to Diarrhoeagenic E. coli. Int.J.Curr.Microbiol.App.Sci. 7(07): 1316-1321. doi: https://doi.org/10.20546/ijcmas.2018.707.157 